\title{
FLORAL VISITORS AND THEIR BEHAVIOR TO SYMPATRIC SALVIA SPECIES (LAMIACEAE) IN MEXICO'
}

\author{
Gregg Dieringer \\ Department of Botany, University of Texas at Austin, \\ Austin, Texas 78713, USA \\ T.P. Ramamoorthy and Pedro Tenorio Lezama \\ Instituto de Biología, Universidad Nacional Autónoma de México \\ Apartado Postal 70-233, Ciudad Universitaria, \\ Delegación Coyoacán, 04510 México, D.F. México
}

\begin{abstract}
A field survey in southwestern Mexico was undertaken to locate and identify sympatrically flowering populations of Salvia and to characterize their visiting bee faunas. Twenty nine species of Salvia were observed and 33 species of bees collected. The most common bee visitors were Bombus species comprising $66 \%$ of the bee species collected. Of the 36 localities visited, $42 \%$ had sympatric, concurrently flowering Salvia species. As many as five flowering Salvia species may co-occur and share pollinating visits from the same bee species. Potential interactions between Salvia species and their pollinating bees are discussed.
\end{abstract}

\section{RESUMEN}

Se realizó un estudio de campo en el suroeste de México con el fin de localizar e identificar poblaciones simpátricas de Salvia en floración, y caracterizar a sus abejas visitantes. Se observaron 29 especies de Salviay se colectaron 33 taxa de abejas. Las abejas visitantes más comunes fueron especies del género Bombus, comprendiendo $66 \%$ de los taxa de abejas colectados. De las 36 localidades visitadas, $42 \%$ contenían especies simpátricas de Salvia floreciendo al mismo tiempo. Se encontraron coexistiendo hasta 5 especies de Salvia y en algunas ocasiones recibiendo visitas de abejas polinizadoras pertenecientes a los mismos taxa. Se discuten las interacciones potenciales entre las especies de Salvia y sus abejas polinizadoras.

\section{INTRODUCTION}

The genus Salvia, although thought to have originated in the Mediterranean, has its greatest diversity in Mexico with approximately 300 species (Epling 1939, Ramamoorthy, unpublished). It is estimated that $88 \%$ of Salvia species are endemic to Mexico. Personal observations have indicated that there are numerous localities where several Salvia species cooccur and flower simultaneously. Salvia possesses what may be the most complicated pollination mechanism within the Lamiaceae in that the anthers contact a pollinator's dorsum via a fulcrum attachment of the filaments to the corolla (Fig. 1). Populations of sympatrically

\footnotetext{
1 This study received support from a grant awarded by CONACYT of Mexico to T.P.R., project PCCBBNA 021142.
} 

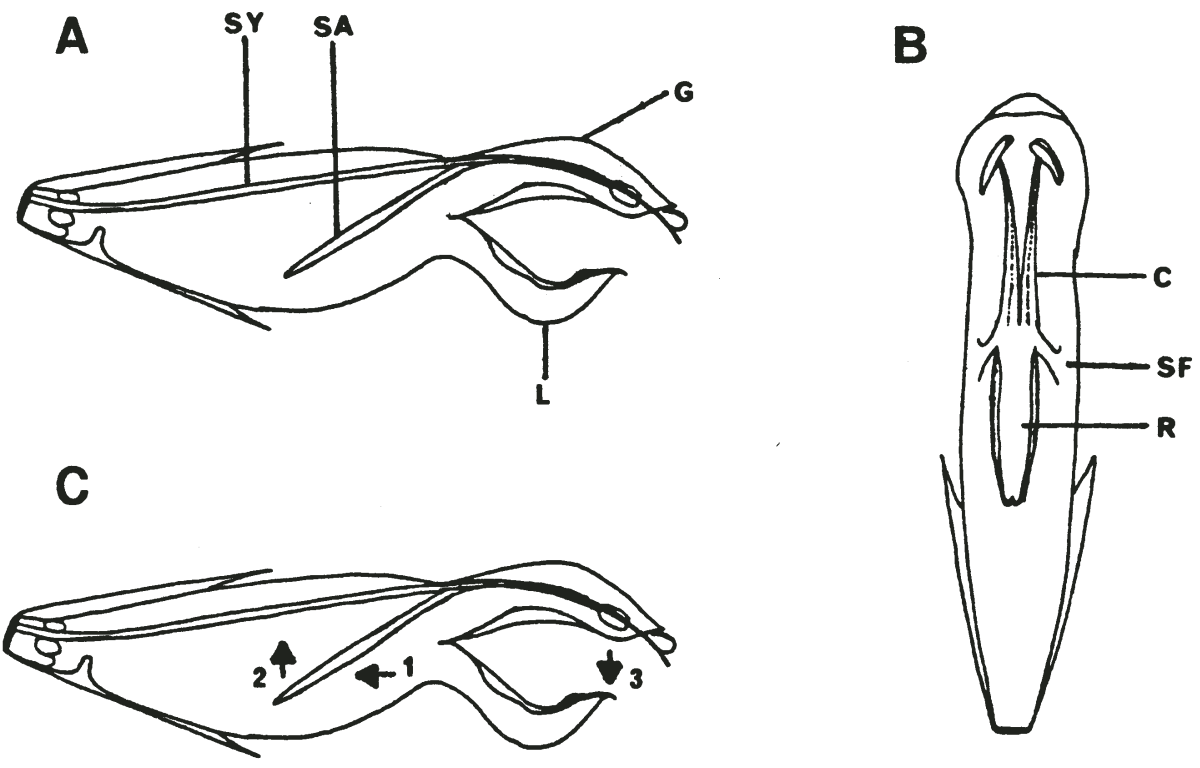

Fig. 1. Flower of Salvia mexicana. A. Side view depicting the stamen (SA), style (SY), galea (G), and lower lip (L). B. Longitudinal view illustrating the relative position and attachment of the staminal filament (SF), connective $(C)$, and rudder $(\mathrm{R})$ to one another. C. Pollen deposition on to a pollinating bee occurs when a bee's tongue is inserted into the flower contacting the rudder (1), pushing it upwards (2), and causing a concomitant downward movement of the connectives (3) on which the anther sacs are located. The anther sacs contact the bee's dorsum and deposit pollen.

flowering Salvia which share pollinators could provide material for studies of the pollination ecology of closely related, sympatric species. Therefore, our objective in this study was to document specific areas of sympatrically flowering Salvia and to identify the major visiting bees and their behavior.

\section{MATERIALS AND METHODS}

During the months of November and December 1985, a wide ranging field survey of southwestern Mexico was taken to locate and identify sympatric Salvia species and their flower-visiting bees. Thirty six localities in the states of Michoacan, Guerrero, Distrito Federal, Morelos, Puebla, and Oaxaca were visited. At each locality, voucher specimens 
of Salvia were collected and deposited at MEXU and TEX (Appendix). Between 60-90 minutes were spent at each locality collecting bees which were visiting Salvia flowers. When 8-10 specimens of a particular bee species had been obtained, collection of that species was halted. If Apis mellifera was observed visiting these flowers, only one specimen per locality was collected. Our primary interest was in native bee species. Individual bee foraging movements were not recorded.

\section{RESULTS}

Salvia species were found in habitats ranging from dry scrub to montane forest, frequently at altitudes above 1000 meters. Habitats with greatest species diversity were those of pine-oak montane forest. A total of 29 Salvia species and 33 bee species were observed and collected. Bombus species were the most common bee visitors comprising $263(66 \%)$ of the 396 bees captured on 24 of the 29 Salvia species studied (Tables 1,2). Other common bee genera included Xylocopa, Deltoptila, Osmia, and Anthophora.

Flowers of Salvia species vary in color from blue/purple to white/cream and red/ pink (Table 2). Generally, blue-and white-flowered Salvia were visited, and presumably pollinated, by bees (based on observations of foraging behavior). All red-flowered Salvia were robbed of nectar by their visiting bees through perforations made at the base of the corolla. Red-flowered Salvia are probably hummingbird pollinated based on color, shape, and absence of any legitimately visiting bees.

Of the 31 observations of bees robbing flowers of nectar, $11(36 \%)$ were of Xylocopa and $12(39 \%)$ of Bombus (Table 2). Of 25 Xylocopa flower visits and 48 Bombus visits, $11(44 \%)$ and $12(25 \%)$ respectively, were visits where nectar was robbed through corolla perforations.

Areas of sympatric, concurrently flowering Salvia species were found to be fairly common especially in pine-oak montane forests. Of the 36 localities visited (Appendix), $15(42 \%)$ had more than one species present. As many as five different Salvia species were observed flowering within a circle of approximately 100 meters in diameter. It was not uncommon to find the same Bombus species pollinating more than one Salvia species at a locality. For example, at Rosario, Michoacan, S. gracilis, S. lavanduloides, S. mexicana, $S$. iodantha, and $S$. fulgens co-occur and flower simultaneously. The former three species are blue-flowered while the latter two are red-flowered. Both $S$. gracilis and S. lavanduloides were pollinated by Bombus ephippiatus. At locality \#34 (see Appendix), B. diligens was observed pollinating both $S$. lavanduloides and $S$. inconspicua, and at Ajusco, D.F., B. nigrodorsalis montezumae pollinated $S$. lavanduloides and $S$. polystachya.

The following data also provide some insight into the floral color preferences and nectar robbing behavior of Bombus within Salvia communities. Of the 258 worker and male bumblebees recorded -5 queens were also collected-, 12 male bumblebees pollinated 2 white-flowered Salvia, no workers were observed on white-flowered Salvia. Four redflowered Salvia were robbed by approximately equal proportions of male (14 or $44 \%$ ) and worker (19 or 56\%) bumblebees. Eighteen blue-flowered Salvia were pollinated predominately by workers (140 or $65 \%)$. 
Table 1. Bees visiting Salvia species in Mexico.

Name of Species

Number Collected

Colletidae

1. Caupolicana (Zikanapis) elegans

2. Colletes sp.

Halictidae

3. Caenaugochlora ctenaugochlora 1

4. Pseudaugochloropsis graminea 5

Megachilidae

5. Anthidium (Anthidium) sp. 2

6. A. (Melanthidium) carri 3

7. Chalicodoma (Chelostomoides) sp. 2

8. C. (Cressoniella) sp. 1

9. Osmia (Diceratosmia) sp. 11

Anthophoridae

10. Anthophora californica

11. A. capistrata 6

12. A. mentana 1

13. Deltoptila elefas 30

14. D. aurolentocaudata 2

15. Exomalopisis (Phanomalopsis) binotata 1

16. Melissodes sp.

17. Thygater (Thygater) rubricata 1

18. Xenoglossodes sp.

19. Xylocopa (Neoxylocopa) sp. 1

20. X. (Notoxylocopa) guatemalensis 9

21. X. (Xylocopoides) cyanea 1

22. X. tabaniformis azteca 19

23. X. tabaniformis melanosoma 11

24. X. tabaniformis tabaniformis 7

Apidae

25. Apis mellifera 9

26. Bombus diligens 38

27. B. ephippiatus formosus 100

28. B. medius 15

29. B. nigrodorsalis montezumae 87

30. B. pennsylvanicus pennsylvanicus 2

31. B. steindachneri 15

32. B. trinominatus 6

33. Psithyrus sp. 1

$\begin{array}{ll}\text { Total } & 396\end{array}$ 
Table 2. Salvia species with their visiting bee species corresponding to Table 1.

\section{Blue/Purple-Flowered Salvia}

S. anastomosans $-29^{*}(1)$

S. breviflora $-7^{\star}(1)$

S. fluviatilis $-5^{*}, 6^{*}, 11^{*} 15^{*}, 31^{*}(1)$

S. fruticulosa $-7^{*}, 9^{*}, 25^{*}, 29^{*}(1)$

S. gracilis $-27^{*}, 13^{*}(1)$

S. helianthemifolia $-27^{*}$ (1)

S. inconspicua $-2^{*}, 4^{*}, 6^{*}, 9^{*}, 19^{*}, 20^{*}, 22^{*}, 24^{*}, 26^{*}, 29^{*}, 31^{*}(4)$

S. keerlii $-9^{*}, 11^{*}, 18^{*}, 25^{*}, 29^{*}$ (1)

S. lavanduloides $-3^{*}, 22^{*}, 25^{*}, 26^{*}, 27^{*}, 29^{*}, 31^{*}, 32^{*}, 33^{*}(7)$

S. longifolia $-12^{*}, 23,25^{*}, 26^{*}, 29^{*}(1)$

S. longispicata $-27^{*}, 29^{*}(1)$

S. mexicana $-13^{*}, 20,27,29(5)$

S. mocinoi $-22^{*}(1)$

S. pannosa $-13^{*}, 27^{*}, 29^{*}(1)$

S. polystachya $-1^{*}, 2^{*}, 9^{*}, 11^{*}, 13^{*}, 14^{*}, 22^{*}, 23^{*}, 25^{*}, 26^{*}, 27^{*}, 28^{*}, 29^{*}, 30^{*}(7)$

S. rhyacophila $-22^{*}, 26^{*}, 27^{*}, 29^{*}(1)$

S. rubiginosa $-4^{*}, 28^{*}(1)$

S. sapinaea $-27^{*}(1)$

S. semiatrata $-4,10,20,22,23,26,27^{\star}, 29(2)$

S. thymoides $-5^{*}, 22^{*}, 23^{*}, 25^{*}, 27^{*}(1)$

S. thyrsiflora $-8^{*}, 20^{*}, 21^{*}, 27^{*}, 30^{*}(1)$

White/Cream-Flowered Salvia

S. albiflora $-27^{\star}(1)$

S. tenoriana $-11^{*}, 23^{*}, 29^{*}(1)$

Red/Pink-Flowered Salvia

S. cinnabarina $-20,25,26,27,29(3)$

S. elegans $-17,22,27,29(1)$

S. iodantha $-13,22,27$ (1)

S. lasiantha $-16,25(1)$

S. longistyla -24 (1)

S. purpurea $-22,24,25,27,29$ (3)

"signifies the bee species as a potential pollinator; those lacking an asterisk were observed robbing the flower through corolla perforations. Parentheses indicate the number of localities observed.

\section{DISCUSSION}

Most blue- and white-flowered Salvia species seem to be able to utilize any species of Bombus as a pollinator. The requirements for pollination are a strong animal visitor with only a short to moderate tongue length. These conditions are easily met by most bumblebee species, and Bombus seems to participate in robbing behavior less frequently than Xylocopa..

One case of possible monophily was observed. Populations of Salvia mexicana were observed at five different localities in three different states plus the Distrito Federal. In every 
case, the only pollinating bee was Deltoptila elefas, which has a very long tongue that corresponds to the long corolla tube of this species.

There is some evidence that bumblebees forage indiscriminately between plant species of similar appearance (Macior, 1970; Thomson, 1981). Therefore, areas of sympatric, concurrently flowering Salvia species generate questions regarding pollinator fidelity and the possible transfer of pollen between different Salvia species. If indiscriminate foraging by bees were to occur between sympatric, concurrently flowering Salvia species, excessive pollen waste and/or reduced seed set could be expected (Campbell, 1985; Waser, 1978).

However, since sympatric, concurrently flowering Salvia are common, it seems unlikely that significant pollen and/or seed loss is occurring within these assemblages. There are a number of possible explanations to account for this: 1) individual bees do not forage indiscriminately; 2) Salvia species are so diverse that they are morphologically different enough, by chance, to avoid the effects of indiscriminate bee foraging; or 3) selection eliminates those species which are morphologically similar and affected by indiscriminate bee foraging.

Male and worker bumblebees robbed the nectar of red-flowered Salvia in equal proportion. It was expected that males would be observed in greater proportion than workers on red-flowered species since males forage only for nectar while workers forage for both nectar and pollen. Bombus workers were observed in greater proportion than males on blue-flowered Salvia which probably is in relation to collecting pollen. The association of white-flowered Salvia with only male Bombus is most likely a result of small sample size.

The effect of nectar robbing on the reproductive success of co-occurring Salvia would also be of interest. Most red-flowered Salvia co-occurring with blue-flowered Salvia were being robbed of nectar by bumblebees. Red-flowered Salvia, therefore, provide and added food resource for bees that were also pollinating blue-flowered Salvia. Does the association of red-flowered with blue-flowered Salvia detract or augment the visitation by bumblebees to blue-flowered Salvia? Clearly, further detailed observations and experiments are needed to understand the complex relationships of sympatric, concurrently flowering Salvia presented here.

\section{ACKNOWLEDGEMENTS}

We would like to thank Beryl Simpson, John Neff, and Leticia Cabrera R. for reviewing earlier drafts of the manuscript. Salvia species were identified by T.P. Ramamoorthy. All bee species except the Anthophorini were identified by Dr. John L. Neff. Anthophorini were identified by Dr. Robert W. Brooks. Katie Bear drew the ilustration of Salvia mexicana.

\section{LITERATURE CITED}

Campbell, D. R. 1985. Pollinator sharing and seed set of Stellaria pubera: competition for pollination. Ecology 66: 544-553.

Epling, C. 1939. A revision of Salvia: subgenus Calosphace. Repert. Spec. Nov. Regni Veg. 110: 1-380. Macior, L. W. 1970. The pollination ecology of Pedicularis in Colorado. Amer. J. Bot. 57: 716-728. 
Thomson, J. D. 1981. Spatial and temporal components of resource assessment by flower-feeding insects. J. Anim. Ecol. 50: 49-59.

Waser, N. M. 1978. Competition for hummingbird pollination and sequential flowering in two Colorado wildflowers. Ecology 59: 934-944.

\section{APPENDIX}

Localities and collection numbers of Salvia species in this study. Vouchers located at MEXU and TEX

\section{Michoacan:}

1.- Mil Cumbres

S. fulgens (Ramamoorthy et al. 4831+); S. inconspicua (Ramamoorthy et al. 4826); $S$. iodantha (Ramamoorthy et al. 4825); S. mexicana (Ramamoorthy et al. 4823); S. mocinoi (Ramamoorthy et al. 4830); S. purpurea (Ramamoorthy et al. 4827)

2.- $3.7 \mathrm{~km} \mathrm{SW}$ of Rosario

S. helianthemifolia (Ramamoorthy et al. 4832)

3.- $8 \mathrm{~km} \mathrm{SW}$ of Rosario

S. fulgens (Ramamoorthy et al. 4841+); S. gracilis (Ramamoorthy et al. 4839); S. iodantha (Ramamoorthy et al. 4837); S. lavanduloides (Ramamoorthy et al. 4838); S. mexicana (Ramamoorthy et al. 4840)

\section{Guerrero:}

4.- $15.7 \mathrm{~km} \mathrm{~N}$ of Iguala

S. fluviatilis (Ramamoorthy et al. 4802)

5.- $6 \mathrm{~km} \mathrm{~W}$ of deviation to Chichihualco from Mexico/Acapulco road

S. breviflora (Ramamoorthy et al. 4803)

6.- $5.2 \mathrm{~km}$ after turn to Filo de Caballo from road to Chichihualco

S. inconspicua (Ramamooorthy et al. 4804)

7.- $9.7 \mathrm{~km} \mathrm{~N}$ of Ayotla

Salvia species (Ramamoorthy et al. 4807)

8.- $11.4 \mathrm{~km}$ of Ayotla

S. polystachya, no voucher

9.- $5 \mathrm{~km} \mathrm{~W}$ of Filo de Caballo

S. cinnabarina (Ramamoorthy et al. 4821); S. mocinoi (Ramamoorthy et al. 4822); S. polystachya (Ramamoorthy et al. 4817)

10.- $1.2 \mathrm{~km} \mathrm{E}$ of Chilapachaca

S. rhyacophila (Ramamoorthy et al. 4822A)

11.- $16 \mathrm{~km} \mathrm{E}$ of Chilapa

S. lavanduloides (Ramamoorthy et al. 4822B)

12.- $2 \mathrm{~km} \mathrm{NW}$ of El Balcon

S. longistyla (Ramamoorthy et al. 4842)

13.- $10.3 \mathrm{~km}$ NW of El Balcon

S. lavanduloides (Ramamoorthy et al. 4845); S. thyrsiflora (Ramamoorthy et al. 4846) 
14.- $5.5 \mathrm{~km} \mathrm{NE}$ of Nueva Delhi

S. sapinaea (Ramamoorthy et al. 4849)

Distrito Federal:

15.- Ajusco, entrance to Tlalpuente, off old road to Cuernavaca

S. lavanduloides (Ramamoorthy \& Dieringer 4758); S. mexicana (Ramamoorthy \& Dieringer 4759, 4760); S. microphylla, no voucher+; S. polystachya (Ramamoorthy \& Dieringer 4761)

Morelos:

16.- $11 \mathrm{~km}$ after the turn to Cuernavaca from Ocuilan

S. iodantha (Ramamoorthy et al. 4763); S. lavanduloides (Ramamoorthy et al. 4764); S. mexicana (Ramamoorthy et al. 4762); S. polystachya (Ramamoorthy et al. 4766)

17.- Cuernavaca, near road exiting to Ocuilan

S. purpurea (Ramamoorthy et al. 4769)

18.- $4 \mathrm{~km} \mathrm{SW}$ of Tres Marias

S. polystachya (Ramamoorthy \& Dieringer s. n.)

Puebla:

19.- $14 \mathrm{~km}$ from Teotepec

S. tenoriana, Ramamoorthy ined. (Tenorio \& Dieringer 10648)

20.- $0.5 \mathrm{~km} \mathrm{~S}$ of San Miguel

S. longispicata (Ramamoorthy et al. 4795)

21.- Tatexea, Sierra Norte de Puebla, $12 \mathrm{~km} \mathrm{~N}$ of San Isidro

S. albiflora (Ramamoorthy et al. 4797)

22.- $5 \mathrm{~km} \mathrm{~W}$ of Zapotitlan

S. rubiginosa (Ramamoorthy et al. 4798)

23.- $6 \mathrm{~km} \mathrm{~W}$ of Ahuacatlan

S. polystachya (Ramamoorthy et al. 4800)

Oaxaca:

24.- $5 \mathrm{~km}$ after Tamazulapan on road to Chilapa from Tamazulapan

S. anastomosans (Ramamoorthy et al. 4773); S. lasiantha (Ramamoorthy et al. 4770); S. polystachya (Ramamoorthy et al. 4771); S. semiatrata (Ramamoorthy et al. 4772)

25.- Cerro Pericon, NW of San Pedro de Nopala

S. pannosa (Ramamoorthy et al. 4777); S. purpurea (Ramamoorthy et al. 4779)

26.- Teposcolula

S. fruticulosa (Ramamoorthy et al. 4783); S. keerlii (Ramamoorthy et al. 4782); S. semiatrata (Ramamoorthy et al. 4784); S. thymoides (Ramamoorthy et al. 4785)

27.- $24 \mathrm{~km} \mathrm{~S}$ of Yolomecatl

S. inconspicua (Ramamoorthy et al. 4790); S. cinnabarina (Ramamoorthy et al. 4791); S. longifolia (Ramamoorthy et al. 4792)

28.- $8 \mathrm{~km} \mathrm{SE}$ of Chocani

S. thymoides (Ramamoorthy et al. 4781)

29.- Huajuapan

S. lasiantha (Tenorio \& Dieringer s.n.) 
30. - Cerro Verde, near Huautla

S. mexicana (Tenorio \& Dieringer 10691*); S. polystachya (Tenorio \& Dieringer 10680*);

S. purpurea (Tenorio \& Dieringer 10686*)

31.- Cerro Adoracion, $E$ of Huautla

S. elegans (Tenorio \& Dieringer 10692*); S. lavanduloides (Tenorio \& Dieringer 10693*)

32.- $93.8 \mathrm{~km} \mathrm{~S}$ along MEX 175 from Tuxtepec to Oaxaca

S. longispicata (Tenorio \& Dieringer 10703*)

33.- $143.3 \mathrm{~km} \mathrm{~S}$ of Tuxtepec on MEX 175

Salvia species (red flowers) (Tenorio \& Dieringer 10704*)

34.- $157.3 \mathrm{~km} \mathrm{~S}$ of Tuxtepec on MEX 175

S. inconspicua (Tenorio \& Dieringer 10706*); S. lavanduloides (Tenorio \& Dieringer 10711*) 35.- $12 \mathrm{~km} \mathrm{~S}$ of Tuixtla

S. inconspicua (Tenorio \& Dieringer 10712*); S. semiatrata (Tenorio \& Dieringer 10713*) 36. - $10 \mathrm{~km} \mathrm{~S}$ of Piedra Larga, towards Puerto Escondido

S. lavanduloides (Tenorio \& Dieringer 10730*); S. nicolsonii Ramamoorthy ined. (Tenorio \& Dieringer 10731*+)

+ no bees observed

*located at MEXU only 